\title{
KOMUNIKASI INSTRUKSIONAL SEBAGAI SARANA PENGEMBANGAN AKTUALISASI DIRI PENYANDANG TUNANETRA
}

\author{
Soraya Sri Anggarawati, Engkus Kuswarno, Slamet Mulyana \\ Universitas Padjdjaran
}

\begin{abstract}
ABSTRAK
Penelitian ini berupaya untuk mengetahui peranan komunikasi instruksional pada Yayasan Mitra Netra (YMN) dalam membantu pengembangan aktualisasi diri penyandang tunanetra. Teori Interaksi Simbolik yang dikembangkan oleh Herbert Blumer dijadikan sebagai panduan teori yang digunakan dalam penelitian ini. Metode yang digunakan ialah metode kualitatif dengan pendekatan studi kasus. Data dalam penelitian ini diperoleh melalui wawancara mendalam, observasi, dan studi kepustakaan. Hasil penelitian menunjukkan bahwa proses komunikasi instruksional secara umum dimulai dari konseling awal (assesment) untuk mengetahui kemampuan, kondisi, dan kebutuhan klien. Konseling awal menentukan program, pelaksanaan, serta evaluasi yang sesuai dengan klien tersebut. Peranan komunikasi instruksional antara pengajar dengan klien di YMN berguna untuk memenuhi kebutuhan juga menghilangkan segala hambatan seorang tunanetra dalam memenuhi kebutuhan aktualisasi diri penyandang tunanetra. Melalui komunikasi instruksional, terjadi interaksi yang menciptakan makna untuk mengembangkan konsep diri, harapan baru, motivasi, dan sikap serta perilaku belajar yang berpengaruh dalam pembentukan kemandirian untuk memenuhi kebutuhan hidup hingga mencapai kebutuhan aktualisasi seorang tunanetra.
\end{abstract}

Kata-kata Kunci: Komunikasi Instruksional, Aktualisasi Diri, Tunanetra

\section{INSTRUCTIONAL COMMUNICATION AS TOOLS OF THE DEVELOPMENT OF BLIND PEOPLE}

\begin{abstract}
The purpose of this research is to know the role of instructional communication as a self-actualization development tool for blind people at Yayasan Mitra Netra (YMN). This research is using a symbolic interaction theory by Herbert Blummer as a guidance. The method of this research is qualitative research using study case approach. The data in this research are obtained through observations, in-depth interviews, and literature reviews.

The Results of this research shows that instructional communication at YMN starts from initial counseling (assessment) to determine the blind client's abilities, conditions, and needs. Initial counseling also determines the program, implementation, and evaluation that fits for the client. The role of instructional communication between teacher and client helps client to eliminate all the obstacles as a blind-man for fulfilling their self actualization needs. Through instructional communication, an interaction has occured. The interaction itself created some meaning for developing a self-concept, new hope, motivation, attitude also learning behavior that may affect them to independently fulfill their needs so that they could achive their self-actualization needs.
\end{abstract}

Keywords: Instructional Communication, Self Actualization, Tunanetra

Korespondensi: Soraya Sri Anggarawati, S.I.Kom. Universitas Padjadjaran. Jl. Raya Bandung Sumedang KM.21, Hegarmanah, Jatinangor, Kabupaten Sumedang, Jawa Barat 45363 Email: sorayasrianggarawati@gmail.com 


\section{PENDAHULUAN}

Menjadi penyandang tunanetra kerap menjadi persoalan hidup seseorang karena keterbatasannya dalam melakukan aktivitas seharihari. Istilah tunanetra digunakan bagi orang-orang yang mengalami luka di indra penglihatan sehingga kemampuan melihatnya berkurang meskipun dapat pula tidak mampu melihat sama sekali (Gunadi, 2011: 124). Menurut hasil Survey Sosial Ekonomi Nasional (Susenas) yang dilaksanakan Biro Pusat Statistik (BPS) tahun 2012, jumlah penyandang disabilitas di Indonesia sebanyak 6.008.661 orang. Dari jumlah tersebut, sebanyak 1.780.200 orang adalah penyandang tunanetra. ${ }^{1}$ Lebih lanjut diketahui bahwa pada tahun 2025 penduduk usia lanjut meningkat menjadi $414 \%$ dibandingkan dengan tahun 1990. Dengan demikian, masyarakat Indonesia berkecenderungan menderita kebutaan 15 tahun lebih cepat dibandingkan penderita di daerah subtropics yang disebabkan oleh katarak. ${ }^{2}$

Manusia sebagai makhluk sosial harus selalu hidup bersama. Manusia selalu hidup bersama secara kolektif dalam kesatuan-kesatuan sosial yang besar maupun kecil. Dalam kesatuan sosial inilah manusia hidup saling berinteraksi, bekerja sama, dan bertukar pengetahuan untuk dapat mencapai tujuan hidupnya (Muchtar, Koswara, Setiaman, 2016:113). Sayangnya, Penyandang tunanetra seringkali mengalami

\footnotetext{
1 “Pelayanan Penyandang Disabilitas Dalam Menggunakan Berbagai Sarana Aksebilitas." Diakses dari http://www.kemsos.go.id/modules.php?name=News\&file=article $\&$ sid $=187$ 65 pada hari Kamis, 17 Maret 2016 pukul 11.36 WIB

${ }^{2}$ Djunaedi, 2010. "Tahun 2020 Jumlah Tuna Netra Dunia Menjadi 2x Lipat.” Diakses dari

https://rehsos.kemsos.go.id/modules.php?name=News\&file=print\&sid=107 7 pada hari Rabu, 23 Maret 2016 pukul 14.55 WIB

${ }^{3}$ Ayu Rachmaningtyas, 2013. Penyandang tunanetra di Indonesia alami diskriminasi. Diakses dari
}

diskriminasi dalam kehidupan bermasyarakat. Ismail Prawira Kusuma, Ketua Persatuan Tunanetra Indonesia (Pertuni) mengatakan, penghambat tercapainya tingkat kehidupan bermasyarakat secara aktif, adalah anggapan tunanetra itu sama dengan sakit. ${ }^{3}$ Sehingga, seringkali menjadi penghalang untuk penyandang tunanetra mendapatkan pekerjaan dan pendidikan yang layak karena tidak mendapatkan surat keterangan sehat. Diskriminasi juga dirasakan oleh seorang anak penyandang tunanetra, yaitu Ahmad. Menurut orang tua Ahmad, "Kehidupan di luar rumah keras banget buat Ahmad, kadang sering dikatain sama temen-temennya. Dasar buta lo bego! "” Begitu kata salah satu orang tua penyandang tunanetra yang ditemui di Yayasan Mitra Netra.

Perlakuan diskriminasi lainnya juga dirasakan oleh Despha Dendi Irawan, seorang penyandang tunanetra dewasa. Despha harus keluar dari sekolah karena kondisinya. Saat itu, Ia merasa tidak ada lagi harapan yang dapat dicapai dalam kehidupannya,

"di situ rasanya saya mentok mbak, tapi akhirnya saya mencoba menerima dan mensyukuri kehidupan baru yang saya jalani. Bangkit, bangkit, bangkit saya bilang. Akhirnya saya mencoba bergabung dengan yayasan tunanetra buat tau apa itu tunanetra, gimana jadi tunanetra, ya yayasannya itu Mitra Netra. 5 http://nasional.sindonews.com/read/799806/15/penyandang-tunanetra-diindonesia-alami-diskriminasi-1383061850 pada hari Kamis, 24 Maret 2016 pukul 06.02 WIB

${ }^{4}$ Hasil percakapan dengan orang tua murid penyandang tunanetra di Yayasan Mitra Netra pada Rabu, 16 Maret 2016 pukul 16.16 WIB

${ }^{5}$ Hasil wawancara dengan Despha Dendi Irawan, salah seorang penyandang tunanetra alumni Yayasan Mitra Netra, pada hari Rabu, 23 Maret 2016 pukul 14.45 WIB. 
Begitu ungkap Despha saat ditanya mengenai bagaimana cara ia keluar dari masa-masa tersulitnya. Bangkit dari keterpurukannya dan mencoba bergabung dengan Yayasan Mitra Netra untuk belajar, rupanya membukakan Despha pintu untuk menjadi motivator, trainer emosional healing, dan penulis buku yang sukses.

Segudang prestasi lainnya juga diraih oleh Dimas dan Esa para client yang pernah merasakan proses belajar di Yayasan Mitra Netra. Yayasan Mitra Netra berhasil membantu Dimas untuk masuk dan melanjutkan studinya di Universitas Indonesia jurusan Sastra Inggris. Juga membantu Esa untuk terus belajar hingga mendapatkan program beasiswa ADS untuk studi S2 ke Australia. ${ }^{6}$

Prestasi yang dimiliki Despha, Dimas, dan Esa merupakan beberapa contoh konkret bahwa pada dasarnya tunanetra dapat mengembangkan aktualisasi dirinya. Aktualisasi diri menurut Abraham Maslow dalam Asmadi (2008) adalah

"kemampuan seseorang untuk mengatur diri sendiri sehingga terbebas dari berbagai tekanan, baik yang berasal dalam diri maupun di luar diri. Dengan demikian, aktualisasi diri pada hakikatnya adalah hasil dari kematangan diri dan tidak semua orang dapat mencapai aktualisasi diri tersebut secara penuh (Asmadi, 2008 : 7)."

Salah satu cara dalam mencapai aktualisasi diri ialah dengan pendidikan. Melalui pendidikan, seseorang dapat mengembangkan potensi dirinya. Menurut Horton dan Hunt dalam Pudjiastiti (2007 :24), "lembaga pendidikan berkaitan dengan fungsi yang nyata (manifes) berfungsi untuk mempersiapkan anggota masyarakat untuk mencari nafkah, mengembangkan bakat perseorangan demi kepuasan pribadi dan bagi kepentingan masyarakat, melestarikan kebudayaan, dan menanamkan keterampilan yang perlu bagi partisipasi dalam demokrasi."

Dengan demikian, ketika seorang individu, dalam konteks ini ialah penyandang tunanetra, memperoleh keempat fungsi pendidikan tersebut dapat dikatakan bahwa individu tersebut telah memiliki kematangan diri, dalam hal ini kematangan diri menurut Maslow merupakan wujud dari aktualisasi diri.

Melalui pasal 31 ayat 1 UUD 1945, setiap warga Negara berhak mendapatkan pendidikan. Para penyandang tuna netra pun memiliki hak yang sama dalam mendapatkan pendidikan. Khusus untuk penyandang tunanetra, program pendidikan yang diterapkan lebih menekankan pengembangan kemampuan kemandirian. Tujuan tersebut ada pada peraturan pemerintah No. 72 Tahun 1991 Bab 2 Pasal 2, yaitu pendidikan luar biasa bertujuan untuk membantu peserta didik yang menyandang kelainan fisik dan/atau mental agar mampu mengembangkan sikap, pengetahuan, dan keterampilan sebagai pribadi maupun anggota masyarakat dalam mengadakan hubungan timbal balik dengan lingkungan sosial, budaya, dan alam sekitar serta dapat mengembangkan kemampuan dalam dunia kerja atau mengikuti pendidikan lanjut.

\footnotetext{
${ }^{6}$ Hasil wawancara dengan Muizzudin Hilmi, Kepala bagian Rehabilitasi Pendidikan dan Diklat di Yayasan Mitra Netra, pada hari Rabu, 16 Maret 2016 pukul 16.30 WIB.
} 
Sebagai perwujudan dari peraturan pemerintah No. 72 Tahun 1991 Bab 2 Pasal 2 maka, pemerintah membentuk lembaga dan program pendidikan untuk para penyandang disabilitas tunanetra. Tetapi menurut Bambang Basuki, salah satu pendiri yayasan Mitra Netra menyatakan bahwa potensi tunanetra untuk dapat mengembangkan diri melalui pendidikan dan perolehan layanan sangat minim, maka beliau bertekad untuk mendirikan lembaga untuk melayani tunanetra agar dapat memilki pendidikan yang berkualitas. ${ }^{7}$ Hal tersebut yang menjadi latar belakang berdirinya Yayasan Mitra Netra.

Yayasan Mitra Netra adalah organisasi nirlaba yang memusatkan programnya pada upaya meningkatkan kualitas dan partisipasi tunanetra di bidang pendidikan dan lapangan kerja. "Menyediakan dan mengembangkan layanan untuk tunanetra," itulah fungsinya, karena konsistensi tersebut, banyak penghargaan yang telah diterima oleh Yayasan Mitra Netra. Salah satunya ialah penghargaan Indonesia Innovates tahun 2013 yang diberikan oleh Google, Ogilvy, dan Kementrian Pariwisata dan Ekonomi Kreatif RI sebagai pahlawan Inovasi Indonesia atas kepeloporannya dalam menggunakan internet untuk kepentingan pendidikan bagi tunanetra. ${ }^{8}$ Yayasan Mitra Netra pun menjadi salah satu pusat sumber layanan yang menyediakan berbagai kebutuhan untuk penyandang tunanetra. Kualitas yang dimiliki Yayasan Mitra Netra ini seringkali menjadikan Yayasan Mitra Netra sebagai panutan lembaga

\footnotetext{
${ }^{7}$ Wawancara program Kick Andy dengan Bambang Basuki (Pendiri Mitra Netra) diakses dari youtube channel mitra netra https://www.youtube.com/watch?v=iZJgujU7B4U
}

tunanetra lainnya untuk belajar dan konsultasi, bahkan instruktur yang ada di Yayasan Mitra Netra seringkali diminta untuk melakukan pelatihan untuk pelatih tunanetra pada lembaga lainnya.

Yayasan Mitra Netra pada praktiknya pun sama dengan panti sosial bina netra yang dibawahi oleh Kementerian Sosial RI dalam mengajarkan keterampilan dasar kepada para penyandang tunanetra. Akan tetapi, Yayasan Mitra Netra tidak memperlakukan para penyandang tunanetra dengan konsep panti. Di mana, para penyandang tunanetra di asramakan di panti tersebut untuk mendapatkan bimbingan fisik, mental, sosial, keterampilan, dan hal dasar sebagainya. Menurut Muiz, kepala bagian rehabilitasi dan diklat Yayasan Mitra Netra, konsep panti sesungguhnya bukan konsep yang tepat untuk tunanetra, tempat terbaik untuk para tunanetra adalah keluarga dan lingkungan sosialnya. Konsep panti membuat kesan eksklusif bagi para penyandang tunanetra, sehingga mengakibatkan nantinya mereka sulit untuk berinteraksi di masyarakat. Selain itu, Yayasan Mitra Netra lebih menekankan pada aspek akademis yang terlihat dari layanan kursus, pelatihan, dan pendampingan belajar, sedangkan panti sosial bina netra lebih menekankan pada aspek keterampilan dasar.

Melaksanakan tujuan pendidikan untuk seorang tunanetra berarti sama halnya dengan sekolah luar biasa dan sekolah inklusi yang dibawahi oleh Kementrian Pendidikan dan Kebudayaan RI. Tentu, Yayasan Mitra Netra

\footnotetext{
${ }^{8}$ Penghargaan dan Prestasi. Diakses dari http://www.mitranetra.or.id/default.asp?page=content\&id=16 pada hari Kamis, 17 Maret 2016 pukul 07.33 WIB
} 
berbeda dalam praktiknya, lembaga ini melakukan proses belajar mengajar yang lebih intens, khusus untuk membantu tunanetra dalam memperoleh pendidikan. Sekolah Luar Biasa atau SLB adalah sistem penyelenggaraan pendidikan khusus yang terpisah dengan anak umum lainnya, di mana anakanak berkebutuhan khusus ditempatkan secara khusus. Saat ini, Sekolah Luar Biasa digabung menjadi tiga kelas khusus, yaitu SLB A untuk tunanetra, SLB B untuk tuna rungu dan wicara, dan SLB C untuk tuna grahita. Penggabungan SLB ini menjadikan proses belajar mengajar untuk para tunanetra tidak fokus dan intensif karena kurikulum yang tidak sesuai, padahal kebanyakan tunanetra pada dasarnya sama dengan kebanyakan orang lainnya, yaitu memiliki tingkat kecerdasan yang sama. Dengan demikian, sekolah terbaik untuk tunanetra adalah sekolah pada umumnya agar para penyandang tunanetra dapat berinteraksi dengan teman-temannya.

Proses belajar mengajar yang terjadi di Yayasan Mitra Netra tidak luput dari komunikasi instruksional di dalamnya. Komunikasi instruksional di yayasan ini terjadi di antara pengajar, atau biasa disebut dengan tutor/instruktur, dan peserta didik tunanetra yang biasa disebut dengan client. Uniknya, tenaga instruktur pada Yayasan Mitra Netra hampir seluruhnya ialah tunanetra. Hal ini dilakukan oleh Yayasan Mitra Netra karena kembali pada prinsip awal yayasan bahwa, yang paling memahami masalah dan kebutuhan para tunanetra adalah tunanetra itu sendiri. Dalam hal ini, setiap kegiatan proses belajar, instruktur memiliki peranan dalam mendorong motivasi belajar siswa.

Komunikasi instruksional adalah proses komunikasi yang dipola dan dirancang secara khusus untuk mengubah perilaku sasaran dalam komunitas tertentu ke arah yang lebih baik (Yusuf, 2010: 2). Lebih Lanjut Yusuf (2010: 3) menyatakan bahwa komunikasi instruksional bertugas mengelola proses-porses komunikasi yang secara khusus dirancang untuk tujuan memberikan nilai tambah bagi pihak sasaran, atau setidaknya untuk memberikan perubahanperubahan dalam kognisi, afeksi, dan konasi atau psikomotor di kalangan masyarakat.

Pada dasarnya, fungsi komunikasi dalam proses belajar mengajar relatif sama, yaitu untuk memberikan informasi, mendidik, menghibur, dan memengaruhi. Pertukaran informasi berupa pesan pembelajaran terjadi dari komunikator kepada komunikan. Yang membedakan komunikasi instuksional kepada penyandang tunanetra ialah cara atau metode, informasi, dan media pembelajaran yang digunakan. Komunikasi instruksional untuk tunanetra pun memiliki tingkat kesulitan yang lebih tinggi. Edgar Dale dalam Mariotti (2009 : 38) melalui model the cone of learning menjelaskan bahwa kemampuan mengingat peserta didik diperoleh dari $10 \%$ membaca, 20\% mendengar, 30\% melihat, serta $50 \%$ audio dan visual. Data tersebut menjelaskan bahwa lebih dari $40 \%$ proses belajar akan lebih efektif ketika menggunakan indera mata. Sedangkan pada kenyataannya, tunanetra tidak 
dapat mengakses informasi pembelajaran yang diperoleh dari aspek visual.

Dalam penelitian ini, peneliti memandang komunikasi instruksional penyandang tunanetra sebagai kasus yang menarik perhatian peneliti untuk diteliti secara kualitatif dengan metode studi kasus. Dengan kondisi keterbatasan dalam penglihatan, para tunanetra yang melakukan pembelajaran di Yayasan Mitra Netra tetap dapat mengembangkan aktualisasi diri dengan pretasi yang diperolehnya. Dengan menekankan aspek subjektif pada Yayasan Mitra Netra terhadap para informan, yaitu beberapa orang yang terlibat langsung dengan aktivitas belajar mengajar di Yayasan Mitra Netra maka, peneliti berusaha untuk memahaminya dengan melakukan wawancara kepada pengelola, pengajar, client, dan orang tua client Yayasan Mitra Netra. Berdasar penjabaran di atas maka, penelitian ini berusaha untuk menganalisis komunikasi instruksional pada Yayasan Mitra Netra dalam pengembangan aktualisasi diri penyandang tunanetra

\section{METODE}

Metode penelitian yang digunakan dalam penelitian ini adalah metode kualitatif dengan pendekatan studi kasus. Pendekatan kualitatif dipilih dengan pertimbangan, kondisi kehidupan penyandang tunanetra yang tidak pernah sama antara satu dengan yang lainnya. Dengan menggunakan pendekatan kualitatif, penelitian ini akan lebih kaya dalam memahami tujuan dan caracara yang dilakukan melalui komunikasi instruksional oleh subjek penelitian kepada penyandang tunanetra. Selain itu, dapat mengambil banyak manfaat, dalam arti membuka peluang untuk lebih memahami komunikasi instruksional sebagai sarana pengembangan aktualisasi diri para penyandang tunanetra di Yayasan Mitra Netra.

Menurut Creswell (2014: 135), penelitian studi kasus adalah pendekatan kualitatif yang penelitinya mengeksplorasi kehidupan nyata, sistem terbatas kontemporer (kasus) atau beragam sistem terbatas (berbagai kasus), yang melalui pengumpulan data yang detail dan mendalam yang melibatkan beragam sumber informasi atau sumber informasi majemuk, dan melaporkan deskripsi kasus dan tema kasus. Penelitian studi kasus tidak cukup hanya bersandar pada satu sumber data, tetapi dibutuhkannya banyak sumber atau multi sources.

Teknik analisis data dalam penelitian ini menggunakan analisis studi kasus berdasarkan urutan dari spiral analisis data yang dikemukakan oleh Creswell. Creswell menyatakan bahwa

"untuk menganalisis data kualitatif, peneliti bergerak dalam lingkaran analisis daripada menggunakan pendekatan linier yang tetap. Seorang analis masuk dengan data teks atau gambar dan keluar dengan laporan atau narasi. Selama dalam spiral analsisi, peneliti bersunggungan dengan beberapa salura analisis yang berputar dan terus berputar.(Creswell, 2014: 254).

Uji keabsahan data dalam penelitian ini meliputi uji kredibilitas data, uji transferability, uji dependability, dan uji confirmability (Sugiyono, 
2005: 121). Di mana, uji kredibilitas data sama dengan menguji kebenaran atau validitas data dalam kuantitatif, uji dependability sama dengan menguji reabilitas atau konsistensi data, dan uji confirmability sama dengan menguji obyektivitas data.

Dalam proses penelitian kali ini, uji kredibilitas data dilakukan dengan cara perpanjangan pengamatan dan triangulasi data. Selanjutnya, peneliti melakukan uji transferability melalui penulisan laporan dengan rinci, jelas, sistematis, dan dapat dipercaya. Sehingga, pembaca laporan dapat memberlakukan hasil penelitian ini untuk diterapkan. Peneliti melakukan uji dependability dengan cara melakukan pengecekan ulang oleh auditor yang independen, dalam hal ini ialah dosen pembimbing peneliti serta penguji saat sidang naskah skripsi maupun skripsi. Begitu juga dengan uji konfirmability.

\section{HASIL DAN PEMBAHASAN}

Data dalam penelitian ini diperoleh dari 14 orang informan yang terdiri dari 2 pengelola YMN, 4 pengajar YMN, 2 client aktif YMN, 2 orangtua murid YMN, 2 mantan client YMN, dan 2 ahli dalam bidang pendidikan khusus tunanetra. Data hasil wawancara serta observasi tersebut ditunjang oleh beberapa sumber pustaka untuk memperkuat data agar analisis yang dilakukan lebih mendalam.

Adapun hasil dan pembahasan pada penelitian ini ialah dalam rangka menjawab pertanyaan awal, yaitu bagaimana proses komunikasi instruksional antara pengajar dengan para klien tunanetra di YMN dalam pengembangan aktualisasi diri penyandang tunanetra.

\section{Proses Komunikasi Instruksional pada Yayasan Mitra Netra (YMN)}

Seluruh aktivitas pendidikan memerlukan komunikasi yang biasa kita sebut dengan komunikasi instruksional. Di Yayasan Mitra Netra, aktivitas pendidikan mencakup program layanan rehabilitasi, pendidikan, dan pelatihan. Ketiga aktivitas tersebut memerlukan peranan komunikasi instruksional khusus dalam menangani para penyandang tunanetra. Ketiga aktivitas pendidikan tersebut bertujuan untuk memandirikan dan mengubah sikap serta perilaku para penyandang tunanetra ke arah yang lebih baik.

\section{a. Rehabilitasi}

Rehabilitasi secara harfiah adalah program yang ditujukan untuk membantu memulihkan seseorang dari penyakit kronis baik penyakit fisik maupun psikologis. Di Yayasan Mitra Netra, rehabilitasi adalah tahapan awal untuk seorang tunanetra yang baru mendaftarkan dirinya saat bergabung dengan Yayasan mitra Netra. Dalam tahapan rehabilitasi, ada 3 fase yang harus dilalui seorang client tunanetra, yaitu konseling, pelatihan orientasi dan mobilitas, serta belajar baca tulis braille.

Ketiga fase tersebut merupakan sebuah tahapan. Pak Muiz menjelaskan bahwa, pertama kali datang ke YMN, seorang tunanetra akan dikonseling yang mana proses konseling ini mencakup asesmen untuk mengetahui kondisi dan 
kemampuan seorang tunanetra. Setelah proses konseling yang mencakup asesmen, seorang tunanetra akan diarahkan, apakah ia perlu melakukan pelatihan OM dan baca tulis braille atau bisa langsung diarahkan pada program pelatihan kursus.

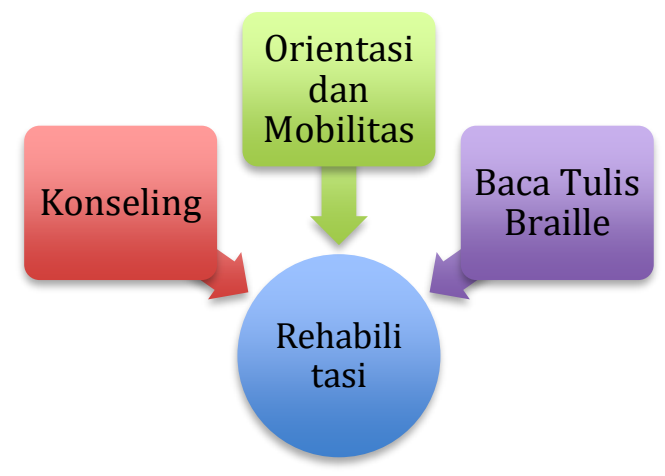

Bagan 1 Fase Rehabilitasi di YMN

Secara keseluruhan, proses komunikasi instruksional program rehabilitasi pada Yayasan Mitra Netra diawali dengan konseling awal/asesmen. Di mana asesmen menentukan fase rehabilitasi apa yang akan diikuti oleh seorang klien. Apakah itu fase konseling, orientasi dan mobilitas, maupun baca tulis braille. Khusus untuk konseling, terdapat tahapan strategi komunikasi yang biasa dilakukan, pertama ialah berteman, kemudian menyimpulkan, serta menasehati. Setelah melalui tahapan tersebut, seorang konselor melakukan evaluasi dengan cara melihat perkembangan kehidupan klien.

Sementara itu, orientasi dan mobilitas serta baca tulis braille dilakukan dengan menggunakan metode komunikasi yang umumnya dilakukan, yaitu dengan ceramah plus diskusi, praktik langsung, pengulangan, dan pemanfaatan indera lain. Adapun evaluasi yang dilakukan ialah dengan cara evaluasi pembelajaran seperti tes tertulis maupun lisan, praktik langsung untuk OM, dan sebagainya.

Evaluasi yang diperoleh dari hasil konseling maupun pembelajaran OM serta baca tulis braille memengaruhi pembentukan sebuah tujuan diadakannya sebuah program Yayasan Mitra Netra untuk dikembangkan agar lebih baik lagi. Tujuan program kemudian memengaruhi kembali pada konseling awal (assesment) yang dilakukan oleh konselor di YMN.

\section{b. Pendidikan}

Program layanan pendidikan ialah sebutan yang mewakili aktivitas pendampingan belajar, kejar paket, dan pendampingan administrasi sekolah pada Yayasan Mitra Netra. Program pendidikan mencakup pendampingan saat masuk sekolah, pendaftaraan, ataupun ketika mengadvokasi agar pihak sekolah, atau pihak perguruan tinggi mau menerima para tunanetra. Setelah diterima menjadi peserta didik baik itu menjadi siswa ataupun mahasiswa, setelah itu baru ada proses pendampingan belajar. Selain itu, YMN pun memfasilitasi para tunanetra yang tidak dapat memperoleh pendidikan formal agar mereka dapat belajar untuk mengikuti ujian kejar paket (baik kejar paket A,B,dan C). Sehingga dengan ijazah kejar paket para tunanetra dapat menempuh pendidikan lebih tinggi lagi. 
Seorang client dapat memperoleh layanan pendidikan ketika ia telah menjalani proses konseling awal. Pada tahap konseling awal, konselor melakukan asemen kemampuan dan kondisi sang client. Melalui tahap itu, konselor menentukan apakah ia harus mengikuti program rehabilitasi atau dapat langsung mengikuti program layanan pendidikan dan pelatihan.

Pertukaran informasi, pikiran, dan gagasan dalam hal ini ialah mengenai pembelajaran yang dilakukan oleh tutor sebagai komunikator dan klien sebagai komunikan yang dilakukan saat proses pendampingan belajar. Komunikasi yang dilakukan dalam proses belajar mengajar adalah dengan konteks komunikasi interpersonal antara tutor dengan klien. Menurut Sendjaja (1993:123) "Komunikasi antarpribadi melibatkan paling sedikit dua orang yang mempunyai sifat, nilai-nilai pendapat, sikap, pikiran dan perilaku yang khas dan berbeda-beda. Dengan kata lain, para pelaku komunikasi saling bertukar informasi, pikiran dan gagasan, dan sebagainya."

Pada program pendampingan belajar di YMN, lingkungan dalam belajar, berbentuk kelas private. Pemilihan bentuk kelas private dipilih karena dalam program pendampingan, kemampuan serta kebutuhan klien berbeda-beda. Misalnya saja, seorang klien meminta untuk didampingi belajar matematika, sementara klien lainnya meminta didampingi mengerjakan tugas atau membacakan buku bahasa Indonesia. Begitu juga dengan kemampuan belajar klien. Misalnya saja klien A tidak memiliki disabilitas lainnya seperti auits, kesulitan belajar, dsb, sementara klien B memiliki disabilitas lainnya. Dengan demikian, cara pengajarannya pun berbeda, sehingga tidak dapat digabung menjadi satu kelas.

Metode komunikasi instruksional di Yayasan Mitra Netra pada program pendampingan khususnya hanya menggunakan metode ceramah plus diskusi dan praktik langsung. Ceramah plus di sini dalam artian tutor mengajarkan terlebih dahulu konsep yang ada, baru kemudian praktik langsung, dengan anak menyentuh alat peraga (bila pelajaran matematika). Penggunaan media pun dilakukan oleh tutor pada YMN untuk memberikan pemahaman secara menyeluruh kepada klien. Seperti halnya alat peraga yang digunakan untuk mempelajari pecahan pada matematika dengan pecahan lingkaran dan persegi yang aksesebel, yang dapat dirabakan, disentuh, sehingga penggambaran konsep dapat terbayang dibenak klien.

Jika mengacu pada konsep pola komunikasi dalam proses belajar mengajar yang dikemukakan oleh Sudjana (2002:31) maka pelaksanaan komunikasi yang terjadi pada program pelatihan di YMN mencakup ketiga pola, yaitu komunikasi satu arah, dua arah, dan banyak arah. Satu arah ketika seorang trainer atau instruktur menjelaskan megenai konsep pembelajaran, dua arah ketika kedua pihak terlibat proses diskusi dan tanya jawab, banyak arah yaitu ketika kedua pihak berinteraksi satu dengan yang lain, juga berinteraksi kepada peserta didik/klien lainnya.

\section{c. Pelatihan}


Program pelatihan mencakup kursus dan pre-employment training. Program kursus yang diselenggarakan oleh Yayasan Mitra Netra terdiri dari kursus komputer, bahasa Inggris, bahasa Jerman, Jarimatika, mengaji dan musik. Sementara itu, pre-employment training merupakan pelatihan yang diperuntukkan tunanetra dewasa yang nantinya akan memasuki dunia kerja.

Perencanaan program pelatihan di YMN secara umum, dengan merancang kurikulum atau biasa disebut silabus pada program kursus dan modul dalam program pelatihan. Silabus dibuat oleh masing-masing instruktur, sedangkan modul dibuat oleh trainer dan ketua pelaksana pelatihan. Di dalam silabus dan modul terdapat materi-materi yang akan diajarkan pada klien. Akan tetapi, dalam silabus, tidak ada strategi khusus yang dijabarkan untuk mengajarkan klien. Hal ini disebabkan srategi atau cara melaksanakan pembelajaran disesuaikan dengan kondisi klien. Sementara itu, dalam modul pelatihan pre-employment training, pelatih sudah menyiapkan strategi dalam menyampaikan masing-masing materinya. Misalnya dengan cara games, dan sebagainya.

Perencanaan program kursus dengan preemployment training saling berhubungan. program kursus dan pre-employment training sama-sama melakukan asesmen untuk mengukur kondisi, kemampuan, dan kebutuhan klien. Perencanaan dalam program kursus diawali dengan asesmen yang dilakukan pada fase rehabilitasi, yaitu konseling. Setelah itu konselor yang menentukan apakah klien bisa langsung mengikuti program kursus. Bila mereka mampu, maka langsung menentukan kapan jadwal yang sesuai dengan waktu instuktur dan klien. Ditentukan juga bentuk kelas untuknya, apakah harus individual atau bisa klasikal.

Ketika masuk ke dalam program kursus, silabus dibuat tidak melalui proses asesmen. Silabus sudah dibuat oleh instruktur untuk diterapkan kepada klien, tidak peduli mereka hanya tunanetra pure atau plus. Pelaksanaannya saja yang disesuaikan dengan kondisi klien. Bila klien masih belum mampu melanjutkan ke materi selanjutnya, maka pelajaran bisa diulangi kembali hingga klien mengerti. Dalam silabus tidak ada target pencapaian yang harus dicapai instruktur.

Apabila klien dinilai mampu dalam melaksanakan pembelajaran kursus, terutama komputer, dan ia telah menguasainya, serta mendapatkan hasil evaluasi yang memenuhi syarat untuk mengikuti pre-employment training, maka ia dapat mengikuti kegiatan pre employment training. Penilaian tersebut merupakan seleksi klien. Selanjutnya, setelah klien terseleksi, ketua pelaksana, dalam hal ini ialah Mbak Aria mengases kemampuan dan kondisi klien. Dinilai dari aktivitas sehari-hari dan bertanya dengan Mas Adi selaku konselor di YMN.

Setelah asesmen, masuk kepada proses perencanaan pembuatan materi serta metode pelatihan. Materi disesuaikan pula dengan kondisi, kemampuan, dan kebutuhan klien. Setelah itu pembuatan modul dan pelaksanaan pelatihan preemployment training.

Pelaksanaan dalam komunikasi instruksional melingkupi bagaimana metode 
komunikasi instruksional yang dilakukan, gaya komunikasi, fasilitas pembelajaran (lingkungan belajar, media pembelajaran), bahan materi pembelajaran, peran pengajar, dan peserta didik. Sinergitas antara keenam komponen tersebut membentuk sebuah pelaksanaan komunikasi instruksional yang efektif.

Pendekatan pembelajaran di YMN pada program pelatihan dilakukan dengan pendekatan kelompok dan individual. Pendekatan kelompok terutama terdapat pada program kursus komputer, bahasa Inggris, dan bahasa Jerman. Kelompok dalam belajar pada program kursus hanya mencakup 3-6 orang. Pendekatan kelompok dapat dilakukan ketika klien atau peserta didik mampu belajar bersama dengan teman-temannya yang lain dan tidak membutuhkan metode pembelajaran khusus. Sementara itu, pendekatan individual juga dapat dilakukan dalam semua program kursus mngacu pada kondisi ketunanetraan klien.

Sementara itu, pada program pelatihan preemployment training, pendekatan kelompok terdiri dari dua jenis kelompok, yaitu kelompok besar yang terdiri dari beberapa kelompok kecil. Di mana, kelompok kecil (terdiri dari 3-5 orang) dibuat untuk mengefektifkan proses pelatihan. Dengan kelompok kecil, para peserta pelatihan/klien ini dapat berdiskusi di antara mereka juga dan dengan pendamping kelompok. Selain itu, kelompok kecil ini juga berguna untuk membantu anggota kelompok lainnya dalam memecahkan masalah juga membantu mengarahkan mereka untuk peduli dengan persoalan pribadi mereka.
Tujuan dari kelompok sama seperti apa yang diungkapkan oleh Adler dan Rodman (dalam Bungin, 2011: 276) yang mengatakan bahwa terdapat 3 tipe kelompok, yaitu kelompok belajar, kelompok pertumbuhan, dan kelompok pemecahan masalah. Di mana, masing-masing kelompok tersebut pada intinya ialah membantu individu untuk belajar, tumbuh, dah memecahkan masalah bersama-sama.

Selanjutnya, teknik pengajaran atau metode komunikasi instruksional yang digunakan secara keseluruhan, baik itu dalam program kursus maupun pre-employment training ialah dengan ceramah, diskusi, praktik langsung, role playing dan games. Metode ceramah banyak dilakukan pada program pelatihan pre-employment training karena trainer banyak memberikan informasi seputar arahan-arahan motivasi untuk mengembangkan diri, cara pengenalan diri diri, dan sebagainya. Begitu juga dengan metode games dan role playing. Agar pelatihan pre-employment training dilaksanakan secara dinamis dan menarik klien diajak untuk melaksanakan games yang bertujuan untuk memaksimalkan potensi dirinya dalam bersosialisasi, bekerja sama, dan mengaplikasikan orientasi dan mobilitas. Sementara itu role playing dilakukan agar klien yang akan mengikuti seleksi kerja mengetahui secara jelas apa-apa saja yang harus mereka lakukan ketika bekerja nantinya.

Praktik metode diskusi dan praktik langsung banyak digunakan dalam program kursus. Diskusi dilakukan agar klien memiliki pemahaman analisis mengenai suatu materi ajar yang juga 
berguna untuk instruktur dalam mengetahui apakah klien memahami dan mengerti informasi pelajaran yang ia berikan. Keterbatasan instruktur dalam melihat ekspresi wajah atau nonverbal seseorang membuat dirinya perlu untuk mengulangi proses tanya jawab hingga instruktur merasa klien sudah mengerti betul bahan yang diajarkannya. Kegiatan praktik langsung tentunya dimaksudkan agar klien memiliki pengalaman sekaligus kesan yang mendalam terhadap sebuah bahan aja yang didapatkan. Contohnya saja praktik komputer. Dengan mudah klien mengingat materi pembelajaran ketika mereka mempraktikan secara langsung tugas-tugas dalam membuat sebuah konten tulisan atau tabel dalam msword, misalnya.

Selain kelima praktik metode komunikasi instruksional yang dilakukan pada program kursus maupun pre-employment training, peneliti melihat bahwa metode lainnya yang sering digunakan ialah metode membelajarkan berulang. Kondisi seseorang dengan keterbatasan melihat membuat mereka sulit untuk mengingat apa yang sudah dipelajarinya, sehingga instruktur, khususnya dalam program pelatihan mengulang materi yang diajarkan hingga 2-3 kali. Berlaku juga untuk tunanetra dengan kondisi memiliki tambahan disabilitas lainnya. metode membelajarkan berulang sangat efektif untuk klien tersebut mengingat serta memahami pelajaran yang telah diberikan sebelumnya.

Secara keseluruhan, praktik komunikasi instruksional tidak akan berjalan apabila tidak dilakukan oleh pengajar. Pengajar biasa disebut dengan instruktur di YMN. Menurut hasil wawancara juga observasi lapangan, peran pengajar pada Yayasan Mitra Netra mencakup sebagai sahabat, sebagai keluarga, sebagai role model, sebagai guru, sebagai manajer, dan sebagai konselor. Hal ini sejalan dengan pendapat Moore dan Parsons (2001: 209) “...secara garis besar peranan guru dibagi manjeadi tiga, yaitu pengajar, manajer, dan konselor."

Ketika seorang mengalami tunanetra saat ia dewasa, maka itu adalah hal tersulit untuknya, namun ketika ia belajar di YMN dan menemukan seorang instruktur yang juga tunanetra dan dapat menjadi sahabatnya, maka ia menemukan kembali kebutuhan kasih sayang dan belongingness dalam kehidupannya. Sementara itu, instruktur sebagai keluarga ialah mereka perlu dekat dengan keluarga klien sehingga, klien maupun keluarganya merasa YMN adalah rumah dengan isi keluarga baru di dalamnya. Sebagai role model dalam artian, pengajar di sini harus seseorang yang benar-benar paham di bidangnya dan melalui pengalaman serta prestasi yang sudah dimiliki oleh para instruktur maupun trainer diharapkan klien dapat termotivasi untuk selalu belajar hingga menguasai bidang yang diajarkan oleh instruktur ata trainer tersebut.

Peranan pengajar juga yang perlu menyiapkan peserta didik, dalam hal ini ialah klien untuk bisa memahami pelajaran yang diberikan dan siap untuk berkembang melalui pelajaran-pelajaran yang diberikan. Ketika peserta didik sudah siap dan mampu, maka proses belajar mengajar akan berjalan efektif dalam meraih tujuannya.

Fasilitas adalah salah satu pendukung lainnya untuk mencapai keefektifan pembelajaran. 
Fasilitas di sini diartikan sebagai media pembelajaran serta lingkungan belajar klien. Media pembelajaran seorang tunanetra dalam program pelatihan ini mencakup laptop, headset, serta recorder. Perkembangan teknologi membuat tunanetra sudah lebih mudah untuk mengakses media pembelajaran. Dengan laptop komputer, yang tentunya sudah difasilitasi dengan software screen reader, mereka akan lebih mudah mengerjakan tugas maupun belajar. Sementara itu, lingkungan pembelajaran pun perlu diperhatikan untuk aktivitas membelajarkan tunanetra. Pertama tempat, Tempat pembelajaran untuk tunanetra harus tempat yang lapang, dalam artian yang terlalu banyak benda yang ada di sekitar mereka. Warna cat dinding, penerangan, dan estetika dari suatu tempat belajar tidak berpengaruh sama sekali untuk klien karena mereka pun tidak dapat melihat keindahan dari tempat belajar tersebut. Yang terpenting ialah mereka nyaman untuk melakukan kegiatan belajar mengajar.

Kedua, lingkungan sosial atau teman. Aktivitas pembelajaran tidak dapat berjalan efektif ketika teman dalam satu kelas yang sama ialah tunanetra dengan disabilitas tambahan yang memerlukan perhatian maupun metode khusus dalam pembelajaran.

Pemilihan materi pembelajaran untuk klien di YMN berdasarkan kebermanfaatannya. Dalam artian, YMN hanya memberikan materi-materi pembelajaran yang memiliki manfaat dalam kehidupan klien. Peranan seorang instruktur maupun klien untuk merencanakan materi pembelajaran yang bermanfaat untuk klien. Selain itu, materi pembelajaran untuk klien di YMN tidak dipaksakan harus tuntas terselesaikan dengan baik. Karena, prinsipnya YMN hanya membantu tunanetra untuk memberikan suatu pengetahuan tambahan untuk mereka, bukan memaksakan mereka untuk menguasai materi-materi pembelajaran yang diberikan.

Untuk mengukur kemampuan kognitif klien pada program pelatihan, Yayasan Mitra Netra menggunakan ragam evaluasi pre-test dan post-test, formatif, serta sumatif. Pada program pelatihan kursus, evaluasi kognitif tidak seluruhnya dilakukan pada setiap jenis kursus. Evaluasi dalam ranah kognitif hanya diterapkan pada kursus komputer, bahasa Inggris, bahasa Jerman, dan Jarimatika. Ragam evaluasi yang digunakan ialah melalui evaluasi formatif dan sumatif. Evaluasi formatif atau yang biasa kita kenal dengan ulangan harian, dilakukan setelah beberapa kali pertemuan, untuk mengetahui pemahaman klien mengenai materi-materi yang sudah diajarkan. Evaluasi formatif biasanya tidak dilakukan secara formal, hanya berbentuk latihan atau tugas yang harus dikerjakan sendiri oleh klien. Apabila evaluasi formatif tersebut belum memenuhi standar, maka instruktur biasanya mengulang materi pembelajaran terlebih dahulu, baru melanjutkan ke materi lainnya.

Evaluasi sumatif dilakukan di akhir pertemuan, ketika semua materi pembelajaran dalam suatu jenjang kelas sudah selesai. Bentuk evaluasi sumatif biasanya ialah dengan ujian tulis atau praktik langsung. Hasi evaluasi sumatif yang 
akan menentukan apakah klien bisa mendapatkan sertifikat atau tidak.

Dalam program pre-employment training, terdapat ragam evaluasi pre-test dan post-test. Keduanya dilakukan untuk mengetahui pemahaman materi yang diberikan dari trainer kepada klien.

Sementara itu, evaluasi afektif hanya dilakukan saat di kelas. Hanya untuk menilai sikap dan perilaku klien dalam menerima pembelajaran. Ketika mereka mau menerima, merespon, menilai, mengoranisasikan, dan menghayati sebuah materi pembelajaran dengan baik yang diberikan oleh instruktur, maka klien dinyatakan sudah memiliki sikap dan perilaku yang baik untuk memperoleh tujuan pembelajaran. Di mana, tujuan utama membelajarkan klien dalam program kursus adalah memenuhi kebutuhan-kebutuhan dirinya untuk menjalani hidupnya sebagai seorang tunanetra. Sehingga, ketika mereka dapat menerima dan merespon pembelajaran dengan baik, instruktur sekaligus dapat menilai bagaimana kondisi dirinya saat itu

Yayasan Mitra Netra memiliki cara unik untuk mengukur kemampuan psikomotorik klien, yaitu dengan Festival Mitra Netra dan observasi keseharian klien. Berdasarkan hasil observasi dan wawancara, peneliti membagi bentuk Festival Mitra Netra, yaitu dalam bentuk Perayaan Hari Ulangtahun Yayasan Mitra Netra dan Unjuk Prestasi. Seperti penjelasan mengenai evaluasi psikomotorik, bahwa untuk mengevaluasi keberhasilan ini adalah dengan observasi. Observasi dalam hal ini diposisikan sebagai tes mengenai tingkah laku, persitiwa, dan fenomena lainnya dengan pengamatan lansgung (Syah, 2011: 196)

Mengukur kemampuan atau keberhasilan proses belajar mengajar biasa dilakukan dengan evaluasi. Pada program pelatihan di YMN bentuk evaluasi secara umum ialah dengan mengukur kemampuan kognitif, afektif, dan psikomotorik klien.

\section{PENUTUP}

Aktivitas komunikasi instruksional pada YMN terdapat pada program Rehabilitasi, Pendidikan, dan Pelatihan yang bertujuan untuk memandirikan serta membantu tunanetra untuk beradaptasi di lingkungan masyarakat. Peranan komunikasi instruksional pada Yayasan Mitra Netra dipengaruhi oleh perkembangan dan manfaat pendidikan untuk para tunanetra dan dilakukan dengan menggunakan strategi komunikasi khusus serta memfasilitasi kebutuhan tunanetra terutama dalam bidang pendidikan dan kebutuhan seharihari

Berdasarkan pada data penelitian yang diperoleh, diharapkan Yayasan Mitra Netra melakukan evaluasi formal berkala kepada seluruh pengelola maupun pengajar terkait dengan program-program yang diberikan agar dapat mengembangkannya jauh lebih baik lagi. Selain itu, pelatihan secara rutin untuk para instruktur, tutor, dan konselor perlu untuk dilakukan agar selalu memiliki wawasan tambahan mengenai halhal menyangkut pendidikan dan penanganan kepada tunanetra, baik itu dari segi strategi 
pengajaran maupun teknologi dan media pembelajaran.

\section{DAFTAR PUSTAKA}

Asmadi. (2008). Teknik Prosedural Keperawatan: Konsep dan Aplikasi Kebutuhan Dasar Klien. Jakarta: Salemba Medika.

Bungin, Burhan M. (2011). Sosiologi Komunikasi, Teori, Paradigma, dan Diskursus Telnologi Komunikasi di Masyarakat. Jakarta: Kencana.

Creswell, J. W. (2007). Qualitative Inquiry \& Research Design. California: Sage Publications, Inc.

Dale, E. (1969). Audiovisual Methods in Teaching. New York: Holt. Rinehard and Winston, Inc.

Goldberg, Alvin A.,\& Larson, Carl E. (2011). Komunikasi Kelompok, Proses-Proses Diskusi dan Penerapannya. Jakarta: Penerbit Universitas Indonesia (UI-Press).

Gunadi, T. (2011). Mereka Pun Bisa Sukses. Depok, Jawa Barat: Penebar Swadaya.

Muchtar, K., Koswara, I., Setiaman, A., 2016, KOMUNIKASI ANTAR BUDAYA DALAM PERSPEKTIF ANTROPOLOGI, Jurnal Manajemen Komunikasi Vol 1 No 1, doi

http://dx.doi.org/10.24198/jmk.v1i1.10064

Mulyana, Deddy. (2004). Ilmu Komunikasi Suatu Pengantar. Bandung: PT. Remaja Rosdakarya.

Mariotti, A. P. (2009). Creating Your Teaching Plan: A Guide For Effective Teaching. Bloomington: AuthorHouse.

Parsons, Richard D., Hinson, Stephanie, Lewis, \& Sardo-Brown, Deborah. (2001). Educational psychology: a practitionerresearcher model of teaching. USA: Wadsworth/Thomson Learning.

Robert, K. Yin. (2000). Studi Kasus, Desain dan Metode. Jakarta: Raja Grafindo Persada.
Sendjaja, Sasa, Djuarsa. (1994). Teori Komunikasi Jakarta: Universitas Terbuka.

Sugiyono. (2008). Memahami Penelitian Kualitatif. Bandung: Alfabeta.

Syah, Muhibbin. (2011). Psikologi Pendidikan. Bandung: Remaja Rosdakarya.

Yusuf, Pawit M. (2010). Komunikasi Instruksional: Teori dan Praktik. Jakarta: Bumi Aksara.

\section{Sumber Jurnal}

Budiati, Atik Catur. (2012). Aktualisasi Diri Perempuan Dalam Sistem Budaya Jawa. Dalam Jurnal Sosiologi DILEMA: Dialektika Masyarakat, Vol. 29 No.1. Hal 13-22. Tersedia: http://sosiologi.fisip.uns.ac.id/onlinejurnal/wpcontent/uploads/2013/07/Dilema_Vol29_1 _2012_compressed.pdf\#page $=16$ [6 April 2016].

Skaff, Laura F.,dkk. (2014). Educator and Parent Views og the Efectiveness of Individualized Learning Plans for Students With Disabilities, Dalam Career Development and Transition for Exceptional Individuals, Vol 39(2). Hal 6878. Tersedia: cdtei.sagepub.com [5 April 2016].

Reicher, S. D., \& Levine, M. (1994a). On the consequences of deindividuation manipulations for the strategic communication of self Identifiability and the self- presentation of social identity. European Journal of Social Psychology, 24,511-24.

\section{Sumber Internet}

Keamanan Ask.fm. diakses di http://safety.ask.fm. (Diakses pada 2 Februari 2016)

Tentang Ask.fm. diakses di http://about.ask.fm/about/. (Diakses Pada 2 Februari 2016) 